\title{
AKTIFITAS FISIK DAN PENGGUNAAN ENERGI PEKERJA LAKI-LAKI DENGAN JENIS PEKERJAAN BERBEDA
}

\author{
Yuniar Rosmalina ${ }^{1}$ dan Dewi Permaesih ${ }^{1}$ \\ ${ }^{1}$ Puslitbang Gizi dan Makanan Depkes RI Bogor
}

\section{ABSTRACT \\ PHISICAL ACTIVITY AND ENERGY EXPENDITURE OF MALE WORKER WITH DIFFERENT ACTIVITY LEVEL}

Daily physical activities considered as main component in estimating energy expenditure for group of community. Data on physical activities of male worker relating to their job/occupation in Indonesian is still rarely found. The objective of the study is to compare daily physical activities and daily energy expenditure of male workers with different of their activity level.

Respondents were 51 male workers considered as light activity level and 50 as heavy activity level. Data collection including anthropometric measurement, physical activities was measured at their job location using combination of observation method and recall method 5 day consecutively. Total energy expenditure was estimated using factorial estimated of total energy expenditure. The results showed that male worker with light activity level spent their time in doing their job significantly longer than high activity level (589 minutes vs. 520 minutes). However in term of the energy cost for their doing the job the male worker with high activity level was higher compared to male worker with light activity level (2273 Kcal vs. $1242 \mathrm{Kcal})$. Mean value daily total energy expenditure was $2408 \mathrm{Kcal} / \mathrm{day}$ for light activity and $3548 \mathrm{Kcal} / \mathrm{day}$ for high activity.

Keywords: physical activities, energy expenditure, male worker.

\section{PENDAHULUAN}

$\mathrm{P}$ erhitungan kecukupan energi seseorang didasarkan kepada hasil pengukuran pengggunaan energi atau energi expenditure yang diperlukan untuk melakukan aktifitas fisik perhari. Pada kelompok dewasa kecukupan energi sama dengan jumlah energi yang digunakan atau dikeluarkan. Penambahan energi diperlukan pada kelompok yang sedang dalam masa pertumbuhan, kehamilan dan menyusui agar semua fungsi fisiologis dapat berjalan ${ }^{1}$. Pada kelompok dewasa pria tidak diperlukan tambahan energi karena pertumbuhan sudah tidak lagi terjadi, maka kecukupan energi yang diperlukan adalah sama dengan energi yang digunakan.

Keseimbangan energi tercapai bila energi yang digunakan sesuai dengan asupan energi dari makanan yang diperlihatkan dengan status kesehatan dan komposisi tubuh yang seimbang.

Ada beberapa metode yang dapat digunakan untuk mengukur "energi expenditure" yaitu secara langsung atau secara tidak langsung. Aktifitas fisik merupakan faktor utama yang membedakan kebutuhan energi, selain itu juga berat badan dan umur. Aktifitas fisik seharí mencakup lama dan jenis aktifitas yang biasa dilakukan akan mempengaruhi jumlah energi yang digunakan.

Pekerja di sektor informal seperti penambang pasir dan pengrajin sandal tentu akan berbeda kebutuhan energinya. Data pola aktifitas kelompok pekerja masih jarang tersedia di Indonesia. Makalah ini akan memberikan gambaran perbandingan aktifitas fisik dan total energi yang digunakan 
melakukan kegiatan seharí-hari. Data ini diharapkan bisa menjadi dasar dalam menentukan kecukupan energi pada kelompok pekerja.

\section{BAHAN DAN CARA}

Penelitian ini menggunakan disain potong lintang dan dilakukan di Kabupaten Bogor selama 10 bulan mulai bulan Maret Desember 2004. Populasi penelitian adalah pekerja laki-laki dengan jenis pekerjaan berbeda (ringan dan berat). Penentuan sampel dilakukan secara purposif berdasarkan lokasi pekerjaan responden dan berdasarkan berat ringannya pekerjaan. Kriteria inklusi yang digunakan adalah berumur 35 -55 tahun, telah bekerja dibidang pekerjaannya selama 5 tahun, sehat secara fisik,bersedia ikut dalam penelitian.

Pengelompokan pekerja didasarkan pada kriteria WHO (2), yaitu :

1. Pekerja berat: adalah 75 persen waktu bekerja dengan beban atau "energy cost" $>7$ kalori per menit seperti pembelah batu, atau buruh tani

2. Pekerja ringan: 75 persen waktu bekerja sambil duduk atau "energy cost" 3 - 5 kalori per menit seperti pengrajin alat rumah tangga atau sepatu.

Sampel penelitian adalah pengrajin sandal di Kecamatan Ciomas Kabupaten Bogor sebagai kelompok pekerja ringan dan pencari batu /pasir di Kecamatan Babakan Madang Kabupaten Bogor sebagai kelompok pekerja berat. Jumlah yang memenuhi syarat adalah 51 orang pekerja ringan dan 50 orang pekerja berat usia 30 - 55 tahun, tidak sedang menderita penyakit menahun berdasarkan pemeriksaan dokter dan pemeriksaan darah serta bersedia ikut dalam penelitian.

Data yang digunakan merupakan bagian dari penelitian "Keseimbangan energi dan Komposisi tubuh pekerja dengan jenis pekerjaan berbeda " dengan besar sampel yang yang terpilih sesuai kriteria inklusi adalah
51 orang pekerja ringan dan 51 orang pekerja berat

Data yang dikumpulkan dengan cara wawancara antara lain meliputi: data identitas dan karakteristik responden (nama, umur, lama bekerja, pendidikan, jenis pekerjaan, alamat).

Pengukuran yang dilakukan untuk data antropometri yaitu berat badan, dengan penimbangan menggunakan timbangan elekrodigital merk Seca dengan ketelitian $0.1 \mathrm{~kg}$. Responden ditimbang dengan posisi berdiri tegak tanpa alas kaki. Tinggi badan diukur menggunakan pita plastik microtoise (ketelitian $0.1 \mathrm{~cm}$ ) dengan posisi badan berdiri tegak tanpa alas kaki, kepala, bahu, bokong dan tumit menempel ke tembok. Lingkar lengan atas diukur menggunakan pita LLA dengan posisi melingkar pada median antara siku dan tulang puncak bahu. Ketebalan lemak diukur menggunakan alat skinfold caliper merk Holtain dengan ketelitian $0.1 \mathrm{~mm}$. Pengukuran dilakukan pada ke empat tempat yaitu bicep, tricep, subscapula dan suprailiaca ${ }^{3}$. Data status gizi digunakan Indek Massa Tubuh yang dihitung berdasarkan hasil pengukuran antropometri, yaitu rasio berat badan dibagi tinggi badan dalam sentimeter kuadrat ${ }^{4}$.

Data penggunaan energi selama 3 hari berturut-turut dengan total 24 jam sehari. Data penggunaan energi dikumpulkan dengan cara pengamatan dan mencatat lamanya tiap kegiatan (menit) yang dilakukan saat bekerja jam 8 pagi sampai jam 3 sore dan dilanjutkan dengan "recall" kegiatan yang dilakukan setelah selesai dari pekerjaan hingga mulai lagi bekerja setiap hari selama 3 hari berturut-turut .

Energi yang digunakan dihitung menggunakan "factorial estimated of total energy expenditure" yaitu perkalian lama waktu yang digunakan untuk masing-masing kegiatan dengan "energy cost" dari masing-masing kegiatan dengan memperhitungkan metabolisme dasar dan berat badan tiap responden ${ }^{5}$.

Kegiatan sehari dikelompokkan menjadi 4 yaitu kegiatan tidur, kegiatan kerja, kegiatan 
diluar kerja dan kegiatan lain-lain. Kegiatan kerja adalah kegiatan yang dilakukan untuk mencari nafkah sesuai dengan pekerjaannnya. Kegiatan luar kerja meliputi kegiatan dirumah seperti kegiatan rumah tangga, menjaga anak, duduk-duduk, nonton televisi dan lain-lain diluar kegiatan kerja. Kegiatan lain yang dimaksud adalah kegiatan seperti mandi, sholat, makan minum.

\section{Analisis data}

Analisis data meliputi analisis univariat yang disajikan berupa sebaran, proporsi ,ratarata dan simpang baku. Analisis bivariat dilakukan untuk mengukur perbedaan nilai rata-rata, perbedaan nilai proporsi dan hubungan antara 2 variabel. Uji t dilakukan untuk mengukur beda antara dua rata-rata. Uji chi-square dilakukan untuk mengetahui hubungan antara proporsi 2 variabel ${ }^{6}$.

\section{HASIL}

\section{Karakteristik responden}

Tabel 1 menunjukkan rata-rata usia, status perkawinan dan jumlah anggota rumah tangga menurut jenis pekerjaan.

Tabel 1

Karakteristik Sampel menurut Jenis Pekerjaan

\begin{tabular}{lccccc}
\hline & \multicolumn{3}{l}{ Pekerja ringan $(\mathrm{n}=51)$} & \multicolumn{3}{c}{ Pekerja berat $(\mathrm{n}=50)$} & $\mathrm{p}$ \\
\hline Umur $<35$ th & 18 & $35.3 \%$ & 12 & $24.0 \%$ & \\
$\quad 35-45$ th & 16 & $31.4 \%$ & 22 & $44.0 \%$ & $>0.05$ \\
$\quad>45$ th & 17 & $33.3 \%$ & 16 & $32.0 \%$ & \\
$\begin{array}{l}\text { Status perkawinan } \\
\quad \text { 1. Menikah }\end{array}$ & 49 & $94.2 \%$ & 49 & $98.0 \%$ & \\
$\quad$ 2. Belum menikah & 2 & $3.8 \%$ & 0 & $0 \%$ & $>0.05$ \\
$\quad$ 3. Duda & 1 & $1.9 \%$ & 1 & $2.0 \%$ & \\
Jumlah ART & & & & & \\
$\quad>=5$ & 14 & $26.9 \%$ & 27 & $54.0 \%$ & $0.026^{*}$ \\
$\quad<5$ & 38 & $73.1 \%$ & 23 & $46.0 \%$ & \\
Pendidikan: & & & & & \\
$\quad$ Rendah (<7 th) & 43 & $82.7 \%$ & 49 & $98.0 \%$ & \\
$\quad$ Menengah (7-12 th) & 9 & $17.3 \%$ & 1 & $2.0 \%$ & $0.016^{*}$ \\
$\quad$ Tinggi $(>12$ th) & 0 & $0 \%$ & 0 & $0 \%$ & \\
\hline
\end{tabular}

- bermakna $p<0.05$

Tabel 1 menunjukkan usia pekerja ringan proporsi tertinggi usia < 35 tahun $(35.3 \%)$ sedangkan pekerja berat proporsi yang tertinggi adalah $35-45$ tahun (44.0\%), namun hasil analisis statistik menunjukkan tidak ada hubungan yang bermakna $(p>0.05)$

Baik pekerja ringan maupun pekerja berat lebih dari 90 persen status perkawinannya adalah sudah menikah, sedangkan berdasarkan jumlah anggota keluarga responden pekerja berat mempunyai proprosi anggota keluarga yang lebih dari 5 lebih tinggi dibandingkan dengan pekerja ringan.

Pendidikan responden pekerja dengan lama pendidikan kurang dari 7 tahun atau hanya mengenyam pendidikan sekolah dasar atau sekolah dasar tidak tamat proporsinya lebih tinggi pada pekerja berat yaitu 98.0 persen dibandingkan pekerja ringan 82,7 
Gizi Indon 2008, 31(2):98-106 ～Aktifitas fisik dan penggunaan energi $\quad$ Yuniar R. dan Dewi P

persen dan hasil analisis menunjukkan adanya perbedaan yang bermakna $(<0.05)$.

\section{Karakteristik Anthropometri}

Hasil pengukuran antropometri yang meliputi penimbangan berat badan, tinggi badan, Lingkar lengan atas, dan ketebalan lemak bawah kulit dapat dilihat pada Tabel 2 .

Tabel 2

Hasil pengukuran anthropometri menurut jenis pekerjaan

\begin{tabular}{llll}
\hline & Pekerja ringan & Pekerja berat & \\
\cline { 2 - 3 } & $\begin{array}{l}\text { Rata-rata } \pm \text { SD } \\
\mathrm{n}=50\end{array}$ & $\begin{array}{l}\text { Rata-rata } \pm \text { SD } \\
\mathrm{n}=51\end{array}$ & $\mathrm{p}$ \\
\hline Berat Badan $(\mathrm{kg})$ & $50.3 \pm 6.32$ & $50.6 \pm 5.51$ & 0.850 \\
Tinggi badan $(\mathrm{cm})$ & $160.5 \pm 5.80$ & $159.0 \pm 4.15$ & 0.146 \\
IMT $(\mathrm{kg} / \mathrm{m} 2)$ & $19.5 \pm 2.07$ & $19.9 \pm 1.64$ & 0.245 \\
LLA $(\mathrm{cm})$ & $24.7 \pm 1.91$ & $25.6 \pm 2.49$ & $0.047^{*}$ \\
Bicep $(\mathrm{mm})$ & $4.06 \pm 1.07$ & $3.22 \pm 0.75$ & $0.000^{*}$ \\
Tricep $(\mathrm{mm})$ & $6.62 \pm 2.38$ & $4.49 \pm 1.22$ & $0.000^{*}$ \\
Subscapula $(\mathrm{mm})$ & $10.83 \pm 2.87$ & $7.40 \pm 1.37$ & $0.000^{*}$ \\
Suprailiaca $(\mathrm{mm})$ & $6.82 \pm 2.79$ & $4.69 \pm 1.46$ & $0.000^{*}$ \\
\hline${ }^{*}$ bermakna $<<0.05$ & & &
\end{tabular}

Tabel 2 menunjukkan rata-rata berat badan, tinggi badan dan IMT responden pekerja ringan dan pekerja berat hampir sama atau tidak berbeda secara bermakna ( $p>$ $0.05)$. Perbedaan yang nyata $(p<0.05)$ terjadi pada lingkar lengan atas, yaitu pada pekerja berat lebih tinggi dibandingkan dengan pekerja ringan; sebaliknya pada lapisan lemak bawah kulit pada 4 posisi menunjukkan hasil yang lebih tinggi pada pekerja ringan. Hal ini bisa dimengerti karena dalam melakukan pekerjaannya pekerja berat banyak menggunakan kekuatan otot lengan yaitu mengangkat batu dengan beban $10-15 \mathrm{~kg}$ berjalan ke penggilingan batu atau mengangkat pasir dan atau membelah batu serta bekerja di bawah terik matahari. Pada pekerja ringan mereka juga lebih banyak menggunakan tangan tapi tenaga yang dikeluarkan lebih ringan walaupun rata-rata mereka bekerja lebih lama (Gambar 1).

Rasio berat badan terhadap tinggi badan mengindikasikan berat badan dalam hubungannnya dengan tinggi badan dan khususnya untuk menunjukkan adanya kelebihan berat badan pada populasi. Saat ini rasio berat badan yang banyak digunakan adalah Indeks Massa Tubuh (IMT) yang dihitung berdasarkan berat badan $(\mathrm{kg})$ dibagi dengan tinggi badan $\left(\mathrm{m}^{2}\right)^{3}$. Pada tabel di atas terlihat IMT pada kedua kelompok pekerja tidaklah berbeda, namun komposisi lengan keduanya berbeda yang ditunjukkan dengan pengukuran ketebalan lemak pada bagian Bicep dan Tricep yang lebih tinggi pada pekerja ringan.

\section{Jenis aktifitas fisik menurut kelompok pekerjaan}

Aktifitas fisik adalah kegiatan yang dilakukan selama 24 jam baik itu ditempat pekerjaan, diperjalanan ataupun di rumah. Untuk melihat adanya perbedaan aktifitas fisik pada kelompok pekerja ringan dan berat selama melakukan pekerjaan dilakukan pengamatan dengan mencatat semua kegiatan dan lama kegiatan selama ditempat pekerjaan. Hasil pencatatan dan pengamatan disajikan 
Gizi Indon 2008, 31(2):98-106 ～Aktifitas fisik dan penggunaan energi $\quad$ Yuniar R. dan Dewi P

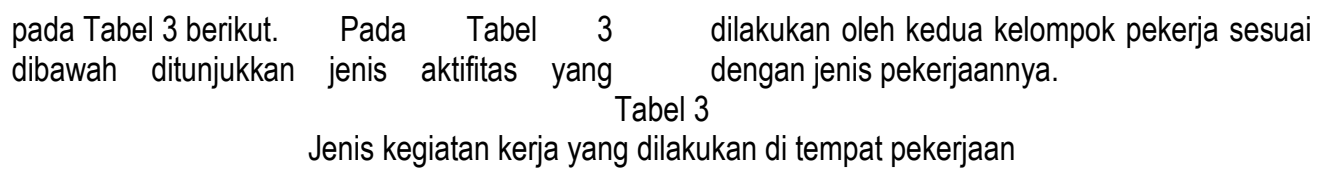

\begin{tabular}{llll}
\hline & Aktifitas Pekerja Ringan & & Aktifitas Pekerja Berat \\
\hline 1 & Jalan ambil bahan & 1 & Berdiri menggali batu dari tebing \\
2 & Jongkok beri latek sol & 2 & Bungkuk menyerok pasir dan koral \\
3 & Duduk buat pola & 3 & Jongkok menyaring pasir \\
4 & Duduk potong pola & 4 & Angkat batu ke truk \\
5 & Duduk Jahit pola/variasi & 5 & Jalan bawa pasir/batu \\
6. & Berdiri gurinda & 6 & Melempar koral \\
7 & Duduk pasang mukaan & 7 & Berdiri memecah batu pancir (besar) \\
8 & Duduk lem sol bawah & 8 & Berdiri memecah batu abrag (kecil) \\
9 & Pasang hak/nyeset sol & 9 & Ambil batu pakai linggis \\
10 & Duduk pasang mata ayam & 10 & Nyangkul \\
11 & Lain2 ditempat kerja & 11 & Garu tanah \\
& & 12 & Naik bawa pasir/batu \\
& & 13 & Jongkok congkel batu \\
& & 14 & Lain2 di tempat kerja \\
\hline
\end{tabular}

Pada Tabel 3 terlihat pekerja ringan banyak melakukan aktifitas dalam pekerjaannya dengan posisi duduk sedangkan pekerja berat melakukan pekerjaan dengan posisi berdiri, atau jalan dengan membawa beban. Dari aktifitas fisik diatas menunjukkan bahwa pembagian kelompok sesuai dengan kriteria dari WHO.

"Energy cost" tiap kegiatan berbeda tergantung dari posisi tubuh dalam melakukan kegiatan. "Energy cost" dengan posisi tubuh duduk lebih rendah dibandingkan dengan posisi berdiri, berjalan atau berlari. Penambahan beban dalam melakukan kegiatan akan meningkatkan energi yang digunakan.

Pola aktifitas fisik

a. Jumlah waktu menurut kelompok aktifitas fisik

Dasar perhitungan banyaknya energi yang digunakan adalah lama waktu yang digunakan untuk setiap kegiatan sehari selama 3 hari berturut-turut dan energi yang dikeluarkan saat melakukan tiap jenis kegiatan.

Gambar berikut menunjukkan rata-rata lama waktu tiap kegiatan yang dilakukan pekerja ringan dan pekerja berat. 


\section{Lama waktu tiap jenis kegiatan}

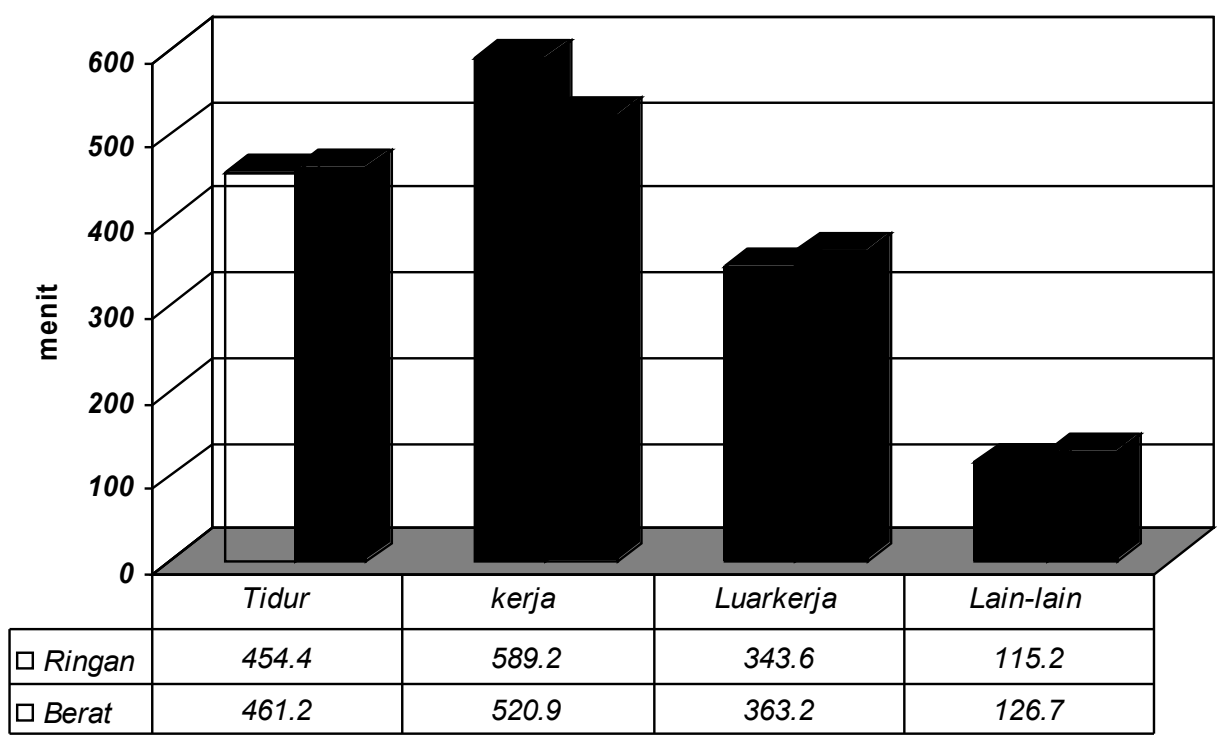

Gambar 1

Lamanya waktu tiap jenis kegiatan yang dilakukan pekerja ringan dan pekerja berat

Pada gambar 1 terlihat lamanya waktu tidur pada pekerja berat sedikit lebih banyak dibandingkan dengan pekerja ringan. Kegiatan kerja adalah kegiatan yang dilakukan untuk mencari nafkah sesuai dengan pekerjaannnya. Pekerja ringan terlihat jumlah waktu yang digunakan untuk kerja lebih lama 1 jam dibandingkan dengan pekerja berat. Hal ini dikarenakan rata-rata pekerja ringan berdomisili di sekitar tempat bekerja dan ada beberapa pekerja ringan yang membawa pekerjaan tersebut ke tempat tinggalnya. Kegiatan luar kerja meliputi kegiatan dirumah seperti kegiatan rumah tangga, menjaga anak, duduk-duduk, nonton televise dan lain-lain diluar kegiatan kerja. Gambar 1 terlihat pekerja berat lebih lama melakukan kegiatan diluar kerja. Kegiatan lain yang dimaksud adalah kegiatan seperti mandi, sholat, makan minum, dan pekerja berat sedikt lebih lama melakukan kegiatan tersebut.

\section{b. Persentase aktifitas sehari menurut kelompok aktifitas fisik}

Pada Tabel 4 disajikan persentase aktivitas menurut kelompok pekerja. Pada Tabel tersebut terlihat bahwa persentase aktivitas kerja secara nyata $(p<0.05)$ lebih tinggi pada pekerja berat. 
Persentase aktivitas menurut kelompok pekerja

\begin{tabular}{lccccc}
\hline \multirow{2}{*}{ Jenis Kegiatan } & \multicolumn{2}{c}{ Pekerja ringan (\%) } & \multicolumn{2}{c}{ Pekerja berat (\%) } & \\
\cline { 2 - 5 } & Rata-rata & SD & Rata-rata & SD & $p$ \\
\hline Tidur & 31.6 & 2.6 & 32.0 & 3.7 & 0.475 \\
Kerja & 40.8 & 5.4 & 36.2 & 5.17 & 0.000 \\
Diluar Kerja & 23.9 & 5.8 & 25.2 & 6.47 & 0.315 \\
Lain-lain & 7.9 & 2.8 & 8.8 & 2.17 & 0.112 \\
\hline
\end{tabular}

Tabel diatas terlihat pekerja ringan menghabiskan waktu 40.8 persen untuk kerja mencari nafkah dan persentasenya terlihat lebih tinggi dibandingkan waktu yang dihabiskan oleh pekerja berat dalam melakukan aktifitas bekerja mencari nafkah $(36.2 \%)$.

\section{c. Energi yang digunakan dalam melakukan tiap kelompok aktifitas fisik}

Gambar 2 menunjukkan rata-rata energi yang digunakan untuk melakukan setiap jenis kegiatan.

\section{Energi yang digunakan tiap jenis kegiatan}

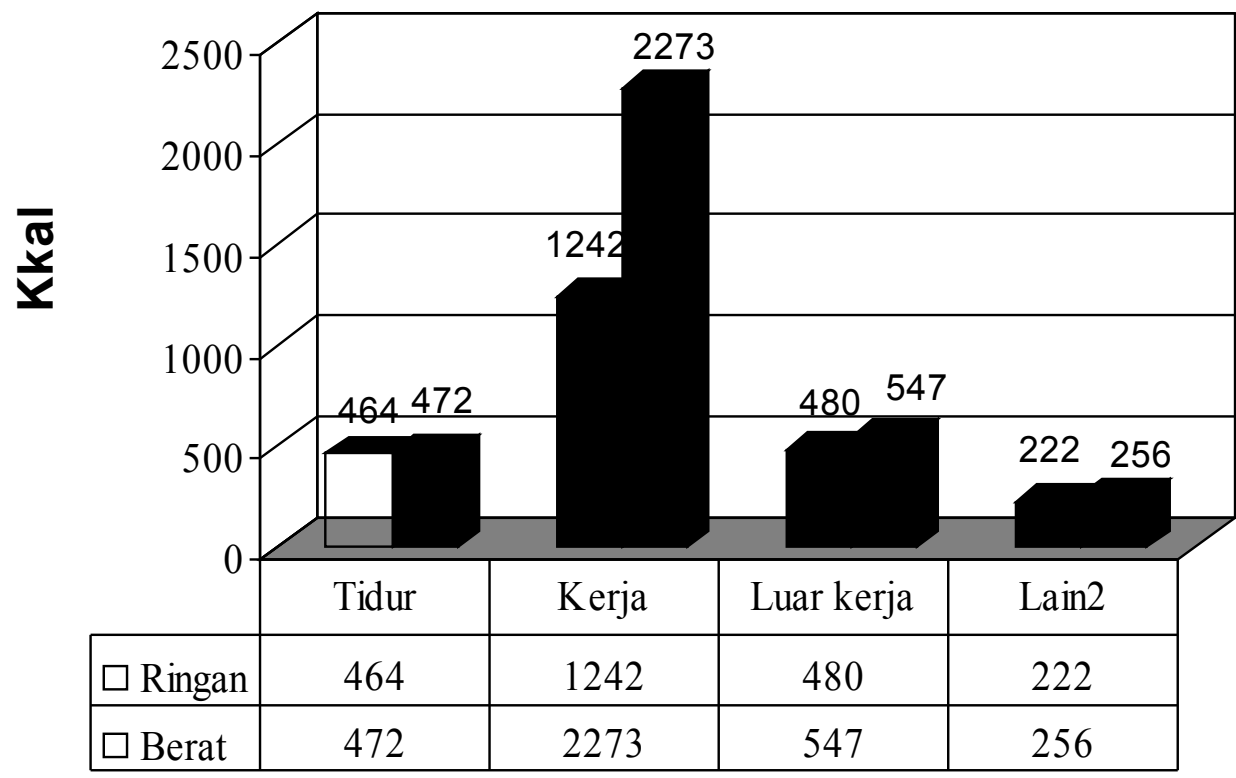

Gambar 2

Energi yang digunakan tiap kelompok kegiatan masing-masing responden

Gambar 2 menunjukkan energi yang digunakan pekerja berat untuk melakukan kegiatan kerja memang lebih tinggi. Hal ini disebabkan "energi cost" tiap jenis kegiatan yang dilakukan lebih tinggi, misalnya memecah batu "energi cost"nya adalah $6-7 \mathrm{kal} / \mathrm{menit}$ 
sedangkan duduk hanya $1.4 \mathrm{kal} /$ menit. Jadi lama dan jenis aktifitasnya akan menghasilkan total energi yang digunakan juga berbeda.

Para pengrajin sandal seperti terlihat pada Tabel 3 melakukan kegiatan kegiatan di tempat kerja sebagian besar dalam posisi duduk walau waktu yang digunakan lebih lama namun karena "energy cost" untuk kegiatan seperti tersebut rendah total energi yang digunakan juga akan lebih rendah seperti terlihat pada Tabel 5 .

\section{d. Persentase energi yang digunakan sehari menurut jenis aktifitas fisik}

Tabel 5 menunjukkan persentase energi yang digunakan masing-masing kelompok aktifitas fisik terhadap total energi yang digunakan selama 3 hari.

Tabel 5

Persentase rata-rata energi yang digunakan tiap jenis aktifitas fisik pada kedua kelompok

\begin{tabular}{lccccc}
\hline \multirow{2}{*}{ Jenis Kegiatan } & \multicolumn{2}{c}{ Pekerja ringan $(\%)$} & \multicolumn{2}{c}{ Pekerja berat $(\%)$} & \\
\cline { 2 - 5 } & Rata-rata & SD & Rata-rata & SD & p \\
\hline Tidur & 19.4 & 2.6 & 13.4 & 2.1 & 0.000 \\
Kerja & 50.9 & 8.6 & 63.6 & 5.8 & 0.000 \\
Diluar Kerja & 20.2 & 5.7 & 15.7 & 4.8 & 0.000 \\
Lain-lain & 9.3 & 4.1 & 7.3 & 2.1 & 0.002 \\
\hline
\end{tabular}

Lebih dari 60 persen energi yang digunakan sehari oleh pekerja berat adalah untuk mencari nafkah dan terlihat energinya untuk bekerja tersebut persentasenya lebih tinggi dibandingkan dengan pekerja ringan.

Tabel 6

Rata-rata penggunaan energi menurut jenis pekerjaan

\begin{tabular}{lccc}
\hline & Hari ke & $\begin{array}{c}\text { Pekerja ringan } \\
\text { Rata-rata } \pm \text { SD }\end{array}$ & $\begin{array}{c}\text { Pekerja berat } \\
\text { Rata-rata } \pm \text { SD }\end{array}$ \\
\hline Penggunaan energi (Kalori) & 1 & $2385 \pm 255$ & $3542 \pm 476$ \\
& 2 & $2432 \pm 233$ & $3565 \pm 443$ \\
& 3 & $2417 \pm 262$ & $3358 \pm 327$ \\
& Rata2 & $2408 \pm 227$ & $3548 \pm 414$ \\
\hline
\end{tabular}

Tabel 6 di atas menunjukkan total energi yang digunakan oleh pekerja berat selama 3 hari rata-rata lebih tinggi dibandingkan pekerja ringan yaitu $3548 \pm 414$ Kkal dan $2408 \pm 227$ Kkal/ hari. Penelitian di China menunjukkan rata-rata energi yang dikeluarkan pekerja tambang/berat adalah antara $4000-4500 \mathrm{Kkal}$ dengan asupan $3100 \mathrm{Kkal}-4000 \mathrm{Kkal}$ sehari (7). Bila dibandingkan dengan AKE 2004 kecukupan yang dianjurkan untuk pekerja ringan dengan kelompok umur $19-49$ tahun ternyata sesuai yaitu antara $2350 \mathrm{Kkal} / \mathrm{hari}$ -
$2550 \mathrm{Kkal} /$ hari (8). Sedangkan penelitian pada pekerja berat di Iran menunjukkan energy yang digunakan sedikit lebih rendah dari responden pekerja berat pada penelitian ini yaitu 3400 Kkal/hari. Namun secara umum untuk pekerja dengan tingkat aktifitas fisik yang berat bisa digunakan sebagai dasar untuk penentuan tingkat kecukupan energinya.

\section{KESIMPULAN}


Penggunaan energi pada pekerja berat selama 3 hari rata-rata (3548 kkal) lebih tinggi secara bermakna dibandingkan pekerja ringan (2408 kkal). Waktu yang digunakan untuk melakukan kegiatan kerja pada pekerja ringan persentasenya lebih tinggi (40.8\%) dibandingkan pekerja berat (36.2 \%), namun pekerja berat memerlukan energi yang lebih tinggi untuk melakukan kegiatan kerjanya.

\section{RUJUKAN}

1. FAO .Food and Nutrition Technical Report Series. Human Energy Requirement. Report of a Joint FAO/WHO/UNU Expert Consultation. Rome 17 - 24 0ctober 2001.

2. WHO. Energy and Protein Requirement. Geneva: WHO, 1985.

3. WHO. Technical Report Series. Physical status: The Use and Interpretation of Anthropometri. Report of a WHO Expert Committee. Geneva 1995
4. Gibson,RS. Principle of Nutritional Assessment, Oxford: Oxford University Press, 2005.

5. Shetty PS, CJK Henry, AE Blake and AM Prentice. Energy Requirements of adults: an update on basal metabolic rates and physical activity levels. European Journal of Clinical Nutrition. 1996; 50, Suppl 1, S11-S23.6

6. Lemeshow,S., David W Hosmer Jr, Janelle Klar and Stephen K Lwanga. Adequacy of sample size in Health Studies. WHO : John Wiley \& Sons, 1990

7. .Hardinsyah. Penentuan Kebutuhan Gizi dan Kesepakatan Harmonisasi di Asia Tenggara. Makalah pada Widya Karya Nasional Pangan dan Gizi VIII Jakarta 17 - 19 Mei 2004. Jakarta: LIPI, 2004

8. Shetty PS. Adaptation to low intakes: the responses and limits to low intakes in infants, children and adult. European Journal of Clinical Nutrition.1999; 53, Suppl 1 S14-S33 